\title{
GRANICE JAŹNI, GRANICE UMYSŁU
}

W korespondencji, którą prowadzili ze sobą w latach 1923-1936 Zygmunt Freud i Romain Rolland, pojawia się określenie „uczucie oceaniczne". Jako pierwszy użył go Rolland. Twierdził, że uczucie to zna z autopsji. Freud natomiast nie krył, że było mu ono obce, i nie przydawał mu takiej wagi jak jego przyjaciel - ale to on upowszechnił w jakiejś mierze przytoczone określenie, komentując w szeroko znanej pracy swoją wymianę myśli z Rollandem (Freud 1998, s. 163-227).

Co to jest za uczucie, czego dotyczy metafora oceanu i o co chodziło Rollandowi? Można je opisać jako przeświadczenie, sytuujące się raczej na poziomie bezpośredniego wrażenia niż intelektu, że jest coś większego niż ja sam czy ja sama; coś, czego dokładniej nie da się określić, bo nie wykazuje żadnych empirycznych cech. Opis to wszelako wielce niedoskonały, by nie rzec: banalny. Można replikować, że w sposób oczywisty istnieją rzeczy większe od nas: szeroki świat, przestrzeń, kosmos, miliony lat historii naturalnej, a w wymiarze duchowym - dokonania wielkich ludzi czy odziedziczona przez nas spuścizna kulturowa. Wszelako dodać trzeba do tego opisu coś jeszcze: to, co na podobieństwo oceanu rozciąga się niemal bezgranicznie, nie tylko jest od nas większe, ale i niezmiernie bliskie w bardzo osobistym sensie. Nie tyle ogrom świata jest wyróżnikiem uczucia oceanicznego, ile przeświadczenie, że nie jesteśmy od niego oddzielni, że jest on jakoś „nasz” albo że zgoła zatarła się granica między naszą podmiotowością a światem, choć zwykliśmy mienić go „zewnętrznym". Postrzegany jest jako coś równie bliskiego czy intymnego jak nasza własna jaźń. Bo też rozciąga się na niego poczucie „siebie”. Spotyka się tu odczucie przestrzennego i czasowego ogromu świata z wypełnieniem go naszą podmiotowością. Przy opisach uczucia oceanicznego padają czasem takie określenia jak ,jedność z przyrodą", „odczucie wieczności” czy „błogość" - ta ostatnia wywołana przez uwalniające przeniesienie uwagi 
z egocentrycznego zaabsorbowania swoimi drobnymi sprawami na wielkie, oceaniczne czy wręcz kosmiczne „ja", daleko wykraczające poza te sprawy.

Twierdził Rolland, że uczucie oceaniczne znane jest ludziom z przeróżnych kultur, z odległych części świata i wyznających różne religie, a mimo to jest przez nich oddawane w podobnych słowach. Nie jest ono uniwersalne, nie wszystkim jest znane, doświadczają go tylko niektórzy - ale możliwość doznania go jest uniwersalna w tym sensie, że nie zależy od konkretnych uwarunkowań społecznych, ideologicznych, kulturowych itp. Twierdził też, że on sam dobrze je zna i że stale mu ono towarzyszy.

Wspomniał o nim w korespondencji z Freudem, ponieważ był ciekaw, jak przyjaciel odniesie się do niego z pozycji psychoanalizy. I srodze się zawiódł. On sam - Rolland - łączył uczucie oceaniczne z mistyką i zdecydowanie miał je za wykraczające poza biologiczne uwarunkowania. W rzeczy samej, można upatrywać w nim podstaw duchowości niezależnej od wszelkiej religii, którą potem różne religie próbują - każda na swój sposób - zinterpretować i zagospodarować. Duchowość może zatem iść $\mathrm{w}$ parze $\mathrm{z}$ religia, ale chociaż nie musi, jest koniecznym warunkiem jej ukształtowania. Tak właśnie widział tę sprawę Rolland. Dodajmy, że jakiś 224 wyznawca może też przejmować ze swej już ukształtowanej religii raczej warstwę doktrynalną zalecenia moralne i tradycyjne rytuały niż duchowość.

Chciał więc Rolland wiedzieć, czy i jakie miejsce znajdzie oceaniczna duchowość w kręgu psychoanalizy. Freud jednak wykazał się daleko idącym redukcjonizmem. Niewątpliwie spoglądał na uczucie oceaniczne z odmiennej perspektywy niż jego korespondent. Miał je za relikt wczesnodziecięcej świadomości, kiedy nie jest jeszcze ukształtowane poczucie siebie jako odrębnej od otoczenia istoty. O ile bowiem, jego zdaniem, wewnętrzna granica jaźni jest nawet u dorosłych rozmyta, a świadomość nie jest ostro odgraniczona od podświadomości, o tyle zewnętrzna granica jaźni jest na ogół dobrze wyznaczona. Nie wiązał w istotny sposób uczucia oceanicznego z religia, której źródeł upatrywał raczej w ukształtowanej w dzieciństwie przemożnej potrzebie ojcowskiej opieki. Jego zdaniem ta potrzeba również zachowuje się $\mathrm{w}$ wieku dorosłym $\mathrm{w}$ jakiejś formie, zwłaszcza że ożywiają i podtrzymują ją różne zagrożenia, jakich w życiu nie brak. Ale choć uczucie oceaniczne nie leży u źródła religii, może ją dodatkowo wspierać. Pozostaje jednak zawsze jakimś regresem, i to niezbyt bezpiecznym: gdyby miało dominować, skutkowałoby według niego nieograniczonym narcyzmem.

Rolland w żadnym razie nie upatrywał w uczuciu oceanicznym ani czysto biologicznych uwarunkowań, ani regresu świadomości. Uzyskał 
odpowiedź na swoje pytanie: psychoanaliza nie sięga poza tego typu wyjaśnienia. Nie usatysfakcjonowała go ta odpowiedź ${ }^{1}$, bo sam widział w uczuciu oceanicznym nie tyle cofnięcie się do okresu, w którym granice jaźni nie były jeszcze ukształtowane, ile raczej przekroczenie zarówno ich, jak i zdolności dyskursywnych, wyjście poza jedne i drugie, niebędące jednak ich unicestwieniem. Są one użyteczne w praktycznym, funkcjonalnym sensie i przy totalnej ich negacji nie byłby zapewne Rolland zdolny odnajdywać się i orientować w życiu codziennym (tak właśnie, jak nie potrafią tego bardzo małe dzieci). A przecież twierdził, że uczucie oceaniczne towarzyszy mu stale, i nie mamy podstaw, by przypuszczać, że zakłócało ono jego codzienne funkcjonowanie.

Znajdujemy u różnych myślicieli z różnych czasów wypowiedzi, które zdają się echami owego uczucia, nazwanego przez Rollanda oceanicznym. Są bardzo niejednorodne pod względem zaplecza kulturowego i intelektualnego autorów oraz celu i stylu przekazu. Przede wszystkim występują u mistyków różnych kultur i czasów (np. u Mistrza Eckharta). Czasem wyrażają się w poezji religijnej (jak u sufickiego mistyka i poety Rumiego). Często wkraczają na teren filozofii, gdzie przyjmują kształt koncepcji metafizycznych, np. u Kena Wilbera, który - podobnie jak zmarły jeszcze przed jego urodzeniem Rolland - krytycznie odnosi się do psychoanalizy i zarzuca jej pomieszanie predyskursywnych stanów umysłu ze stanami postdyskursywnymi (Wilber 2002). Psychoanaliza miałaby właśnie błędnie sprowadzać postdyskursywne, wykraczające poza ratio uczucie oceaniczne (by pozostać przy określeniu Rollanda) do predyskursywnych stanów nieświadomości.

Inne echa tego uczucia znajdujemy w ostatnich dekadach na terenie (o, ironio losu!) pewnie bliższym Freudowi niż metafizyka, mianowicie w praktyce terapeutycznej. Coraz szerzej stosowana jest - i to zarówno $\mathrm{w}$ psychoterapii, w chorobach somatycznych dla poprawy ogólnego stanu pacjentów czy ulżenia im w bólu, jak i w celach rozwoju osobowości - praktyka uważności, uciszająca dyskursywne myślenie, otwierająca umysł na bezpośrednie, wolne od wewnętrznego komentarza doświadczanie chwili obecnej i wskutek tego na niepodtrzymywanie sztywnych struktur myślowych odgraniczających nas od świata. Zdaje się zmierzać w kierunku uczucia oceanicznego, choć nastawiona jest na prostsze cele niż wzniosłe stany umysłu czy głębokie przeżycia. Praktyka ta, dla której przyjęła się angielska nazwa mindfulness, oraz skutki jej stosowania są przedmiotem badań laboratoryjnych, dostarczających świadectw jej użyteczności. Jednym z pionierów zastosowania świadomej uważności

${ }^{1}$ Niemniej cenił Rolland Freuda tak bardzo, że w 1936 r. zaproponował go jako kandydata do Literackiej Nagrody Nobla, będąc już sam jej laureatem. 
w praktyce medycznej jest Jon Kabat-Zinn, lekarz, którego metoda, inspirowana tradycją duchową, rozpowszechnia się coraz bardziej (Williams i in. 2013; Kabat-Zinn 2014). Za rosnącą popularność płaci ona jednak cenę coraz bardziej powierzchownego stosowania.

Ale są jeszcze inne filozoficzne wątki, w których rozpoznać można wcale nieoczywiste paralele z uczuciem oceanicznym. Nieoczywiste, bo zdają się one dalekie od opierania się na jakimkolwiek wewnętrznym przeświadczeniu czy uczuciu, a już na pewno odległe są od mistyki. Przeciwnie, zdają się pozostawać w kręgu ratio i nie wykraczać poza niego.

Chodzi o żywe w ostatnich dekadach kierunki dociekań z obszaru filozofii umysłu, które w zobiektywizowany sposób zmierzają do formułowania koncepcji pojmujących umysł szerzej, niż podpowiada tradycja filozoficzna czy intuicje potoczne ${ }^{2}$. Inspiracje do ich powstania bywały bardzo różne, np. coraz szerszy udział techniki w życiu społeczeństw i coraz dalej idąca nasza od niej zależność, kolejne świadectwa neuronaukowe dotyczące pracy mózgu, rosnąca świadomość wagi zagadnień ekologicznych, naszych związków ze środowiskiem i naszej od niego zależności, dystans do tradycyjnej koncepcji podmiotowości w związku z globalizacją zagęszczaniem sieci naszych powiązań ze światem zewnętrznym, z innymi ludźmi i społecznościami, wreszcie może także wpływ właściwego 226 dla krajów Wschodu sposobu myślenia i odbierania świata ${ }^{3}$. Charakteryzuje go prymat całości przed częścią procesu przed obiektem, relacji przed cechami, społeczności przed jednostką konkretu przed abstrakcją praktyki przed teorią. To, co u nas pod nazwą "uczucia oceanicznego" znalazło sobie miejsce na uboczu zasadniczych nurtów myśli filozoficznej jako pewna osobliwość, tam wpisane jest niejako w potoczną mentalność ${ }^{4}$.

To właśnie idea poszerzenia umysłu łączy wspomniane koncepcje z uczuciem oceanicznym - choć dzieli je od niego z pewnością metodologia, a zwykle i zamierzenie badawcze. Chodzi w nich nie tyle o jakiekolwiek „poczucie” ani (na ogół) o zaspokajanie potrzeb duchowych, ile o intelektualne wypracowanie nowych koncepcji umysłu, lepiej oddających intuicje ukształtowane przez współczesny świat. Jako ludzie Zachodu możemy mieć przede wszystkim predylekcje do zobiektywizowanego, racjonalnego myślenia i cenić takiego właśnie myślenia rezultaty.

Co ciekawe, pewien tego rodzaju trop znajdujemy u Freuda. Aby móc sensownie wypowiadać się o uczuciu oceanicznym, potrzebował mieć

${ }^{2}$ O ile w kręgu myślicieli, którym bliskie jest uczucie oceaniczne, mówi się raczej o przekraczaniu granic jaźni, o tyle w filozofii umysłu mówi się oczywiście o takim czy innym określaniu granic umysłu - stąd dwuczęściowy tytuł niniejszego tekstu.

3 Już Rolland postulował nową teorię umysłu, inspirowaną koncepcjami wschodnimi, por. (Maharaj 2017).

${ }^{4}$ Dokładniej rozwijam tę kwestię w pracy (Jedynak 2014). 
jakieś o nim pojęcie. Wszelako, jak wyznał, nie znał go z autopsji ani nie znał jego zewnętrznych oznak fizjologicznych. Nie żywił też potrzeb, które prowadziłyby do jego ukształtowania. Zatem ani perspektywa pierwszej, ani trzeciej osoby nie wydawała mu się dostępna. W tej sytuacji pozostało mu jedynie pewne wyobrażenie, powstałe dzięki skojarzeniom i porównaniom. Skutek był taki, że odnoszenie się do uczucia oceanicznego przybrało u niego charakter, jak twierdził, nie tyle przeżycia, ile wglądu intelektualnego, któremu wprawdzie towarzyszyło zabarwienie uczuciowe, ale w umiarkowanym stopniu, w takim, jak to zwykle bywa przy różnych aktach myślowych. Był to dostęp wielce niedoskonały i zapewne zniekształcający, czego wyrazem jest np. zdumienie Freuda tym, jak to możliwe, aby jakiekolwiek uczucie odmienne od artykułowanego sądu miało nas pouczać o naszym miejscu we wszechświecie. (Nasuwa się tu porównanie do człowieka, który pewną dziedzinę zna jedynie z pośrednich, werbalnych świadectw, nie zna jej natomiast ze świadectw bezpośrednich, nie wie, że są one w ogóle możliwe, i trudno mu takowe sobie wyobrazić. Może się zdumiewać, skąd o tej dziedzinie wie cokolwiek ktoś inny, komu nie były dostępne o niej żadne artykułowane sądy). I dlatego zapewne rezultat Freudowskiej refleksji nad uczuciem oceanicznym nie zadowolił Rollanda, któremu było ono, jak twierdził, bezpośrednio dostępne.

W każdym razie widoczne jest u Freuda podejście $\mathrm{z}$ intelektualnego punktu widzenia do kwestii poszerzenia granic jaźni. Taką też drogą poszli na ogół, bez wyraźnej, a zapewne i bez żadnej zgoła inspiracji wewnętrznym uczuciem oceanicznym, autorzy przedstawionych niżej koncepcji. Wobec problemów umysłu zajmowali pozycję trzeciej, a nie pierwszej osoby, i nic w postawionych przez nich problemach nie było takiego, co przedkładałoby pierwszą osobę nad trzecią. Toteż oszczędzone im były trudności, jakie napotkał Freud, niemający wystarczających narzędzi do badania nieznanego mu wewnętrznego poczucia. Nie rozczarowaliby Rollanda, ale nie wiadomo, czy w ogóle wzbudziliby jego zainteresowanie.

Wypracowane przez nich koncepcje są dobrze znane i żywo dyskutowane $\mathrm{w}$ zachodniej literaturze, natomiast na naszym gruncie są mniej głośne.

Pierwsza z nich to koncepcja umysłu rozszerzonego. Inspiruje ją refleksja nad technologicznym zapleczem poznania, zwielokrotniającym możliwości umysłu. Podobną inspiracją kieruje się transhumanizm, dla którego gorącym tematem jest perspektywa zaistnienia istot hybrydowych, biologiczno-technicznych, będących rezultatem rozwoju sztucznej inteligencji i wspomagania naszych zdolności poznawczych poprzez wszczepianie ludziom w mózgi urządzeń elektronicznych. W wypadku 
istot hybrydowych zamazaniu ulega fizyczna granica między umysłem tradycyjnym a rozszerzonym. Koncepcja umysłu rozszerzonego, choć nie aż tak dalece wybiega $\mathrm{w}$ techniczną przyszłość, idzie $\mathrm{w}$ podobnym kierunku, co coraz bardziej żywe obecnie transhumanistyczne dyskusje o granicach człowieczeństwa.

Koncepcja ta powstała z tzw. aktywnego eksternalizmu, stawiającego pytanie o to, gdzie kończy się umysł, a zaczyna reszta świata, skoro otoczenie nie tylko wspiera pewne procesy poznawcze, ale i zdaje się czasem dla nich konstytutywne. Ludzki organizm tworzy z pewnymi zewnętrznymi obiektami system, zapewniający możliwość wzajemnych interakcji, podejmowanych w celach poznawczych, wskutek czego procesy poznawcze należy uznać za przebiegające w całym tym systemie. Zlokalizowanie ich nie tyko w mózgu, ale i poza nim oznacza poszerzenie granic umysłu. Do rozszerzenia tego należą np. notes czy komputer. Pełnią analogiczne funkcje co nasze szare komórki: służą zachowywaniu i przetwarzaniu danych. Nie ma funkcjonalnej różnicy między magazynowaniem i przetwarzaniem ważnych dla nas informacji w korze mózgowej a korzystaniem $\mathrm{w}$ tych celach $\mathrm{z}$ zewnętrznych nośników. Usunięcie z systemu poznawczego zewnętrznych w stosunku do mózgu komponentów skutkuje ustaniem behawioralnych przejawów poznania, tak samo jak w wypadku usunięcia pewnych części mózgu (a mówiąc prościej: ten, kto zgubił notes czy mapę, nie jest $\mathrm{w}$ stanie trafić $\mathrm{w}$ określone miejsce, podobnie jak gdyby postradał szare komórki przechowujące pamięć o trasie). Granice rozszerzonego umysłu, obejmującego notes czy komputer (a dziś chciałoby się też dodać: wszczepione do mózgu chipy), miałyby być wyznaczone właśnie przez kryterium funkcjonalne, zgodnie z którym rozszerzony umysł współkonstytuują te wszystkie obiekty, które w interaktywnym połączeniu ze świadomym umysłem pełnią tego samego rodzaju funkcje co te, które spełnia i on (Clark, Chalmers 1998).

Taka była najwcześniejsza koncepcja rozszerzonego umysłu, który zgodnie z nią miał przekraczać granice ciała i obejmować rekwizyty podtrzymujące poznanie, tworząc pewien niejednorodny agregat. Miałyby do niego należeć obiekty bardzo odmienne kategorialnie, a nadto inaczej w procesie poznawczym funkcjonujące: np. pamięć biologiczna wrażliwa jest w szczególny sposób na upływ czasu czy na przeżycia emocjonalne, a pamięć zewnętrzna - nie. Toteż koncepcja ta spotkała się z krytyką jako nieintuicyjna: dlaczego obiekty tak różnej natury jak myślący umysł i zapisana kartka papieru miałyby być uznane za zbiorowy przedmiot? Czy owa kartka jako część umysłu miałaby być zdolna do myślenia? (Adams, Aizawa 2009).

Pod wpływem tej krytyki koncepcja rozszerzonego umysłu została zmodyfikowana. Uznano go nie tyle za statyczny obiekt o hybrydowej 
naturze, ile za dynamiczny niejednorodny kompleks, neurofizjologiczny proces poznawczy wraz ze zróżnicowanym podłożem, na którym przebiega (Menary 2009). Od poszczególnych części tego kompleksu nie trzeba wymagać jednorodności. Ich zróżnicowanie jest korzystne: nośniki pamięci zewnętrznej mają pewne walory, których nie ma pamięć biologiczna, i vice versa. Wewnętrzne i zewnętrzne części umysłu rozszerzonego uzupełniają się wzajemnie, a łączy je to, że stanowią bazę szeroko rozumianego procesu poznawczego, $\mathrm{z}$ włączeniem jego behawioralnych objawów. Podobnie zresztą jest w obrębie samej biologicznej konstrukcji: pewne funkcje zrealizowane być mogą za pomocą różnych jej części. Na przykład emocjonalna reakcja na bodźce może nastąpić za pośrednictwem samego systemu limbicznego lub za pośrednictwem kory mózgowej. To, który układ się zaktywizuje, zależy często od tego, który z nich okaże się w danej sytuacji przydatniejszy (układ limbiczny charakteryzuje się szybkością działania, a kora mózgowa - zdolnością do starannego ważenia racji).

Rozszerzenie procesów poznawczych, a w konsekwencji - umysłu, nie musi ograniczać się do materialnych urządzeń zewnętrznych. Może nadto obejmować relacje społeczne. Na przykład dyskusja jest podłożem procesu poznawczego, który nie mógłby zaistnieć w obrębie jednego mózgu. Powiada się w tym kontekście o dystrybucji umysłu (distributed mind). Może to rozszerzenie obejmować także strukturę abstrakcyjną jaką jest język. Podobnie jak inne narzędzia, język poszerza umysł i przydaje mu skuteczności, pozwalając odnosić się także do tego, co nie jest akurat bezpośrednio dostępne. Intensyfikuje przy tym relacje społeczne i wskutek tego współtworzy bazę dla poszerzenia możliwości poznawczych na niedostępną wcześniej skalę. Według zwolenników tego ujęcia właściwie dopiero z powstaniem języka można mówić o wykreowaniu umysłu na bazie mózgu. To wtedy ludzka inteligencja wzrosła niepomiernie, choć rozmiary mózgu pozostały niezmienione (Logan 2007).

Trzeba podkreślić, że na gruncie koncepcji umysłu rozszerzonego na ogół umysł nie jest tym samym co zwyczajowo pojęta świadomość i że eksponowane są tu inne jego funkcje niż świadome myślenie, intencjonalność czy samoodniesienie ${ }^{5}$. Właśnie takie odbiegające od tradycji pojmowanie umysłu pozwoliło na niespotykane wcześniej wyznaczenie jego bardzo obszernych granic, bez niepożądanej konsekwencji myśli głoszącej, że wszystkie elementy hybrydowego umysłu są nośnikami świadomości. Owszem, są nośnikami np. pamięci - ale już nie świadomości.

${ }^{5}$ Zdarza się jednak niekiedy, że w „umysł rozszerzony” włączana jest i świadomość, por. (Loughlin 2019). 
Wyrażenie „umysł rozszerzony" kojarzone jest z przedstawioną koncepcją (Extended Mind Theory) w różnych jej wersjach, choć etymologicznie rzecz biorąc, pasowałoby także do wielu innych koncepcji idących coraz dalej właśnie $\mathrm{w}$ poszerzaniu granic umysłu - ale zmierzających $\mathrm{w}$ tym kierunku z innych względów. Nie chodzi w nich bowiem o objęcie pojęciem umysłu urządzeń czy obiektów wspomagających go, przejmujących we współpracy z nim jego zadania czy poszerzających jego możliwości, lecz o wstępne warunki niezbędne do tego, aby umysł mógł w ogóle zaistnieć i funkcjonować.

Koncepcja ucieleśnionego poznania (czy ucieleśnionego umysłu) wskazuje, że podmiotem poznania nie jest sam mózg, ale mózg połączony z ciałem. W szczególności zasadnicze znaczenie poznawcze ma nasze wyposażenie sensomotoryczne, które łączy go z otoczeniem i pozwala na ich wzajemne interakcje. Receptory rozmieszczone w ciele, ale poza mózgiem, przekazują do niego sygnały o bodźcach z otoczenia, na co często odpowiada on aktywizacją systemu motorycznego i prowadzi do zmian w otoczeniu.

Koncepcja ta podkreśla rolę procesów sensomotorycznych w kształtowaniu naszych najbardziej podstawowych zdolności poznawczych i sposobów rozumienia świata i samych siebie. Umysł może się ukształtować, tylko operując, dzięki naszemu wyposażeniu cielesnemu, na jakimś materiale empirycznym, i nie zaistnieje bez tego rodzaju pożywki. Z kolei bardziej złożone zdolności poznawcze wyrastają z tych prostych. Ostatecznie wszelka nasza wiedza o świecie i zdolność odnajdywania się w nim wywodzi się z procesów sensomotorycznych (Lakoff, Johnson 1999). Ta idea podważa przekonanie o ostrej granicy między naszym ciałem i umysłem. Ciało i umysł mają stanowić jedność poznawcza, a idea umysłu sprowadzonego do samego funkcjonowania szarych komórek to tylko rezultat abstrakcji dokonanej na tej całości.

W tym punkcie nietrudno już o kolejny krok, toteż koncepcja poznania ucieleśnionego na ogół jest poszerzana do koncepcji poznania usytuowanego czy zagnieżdżonego, a określenia te wypowiada się jednym tchem (embodied embedded cognition; przy czym zamiennie używa się określeń embedded cognition i situated cognition) (Pecher, Zwaan 2005; Robbins, Aydede 2009). Wszak procesy sensomotoryczne możliwe są tylko w interakcji $\mathrm{z}$ otoczeniem, zatem konieczne jest, aby były w nim zagnieżdżone (usytuowane). Dla umysłu konstytutywne jest nie tylko ciało, ale i otoczenie. Genetycznie zagnieżdżone są w otoczeniu wszelkie procesy poznawcze, także te najbardziej abstrakcyjne, gdyż wszystkie wywodzą się ostatecznie $z$ procesów sensomotorycznych. Umysł usytuowany to podmiot poznania usytuowanego, a w praktyce używa się tych określeń niemal zamiennie. Nie o to tu przy tym chodzi, że tradycyjnie pojęty umysł, którego 
siedliskiem miałby być mózg, wchodzi w interakcje z ciałem czy z otoczeniem. Nie. Bez ciała i otoczenia po prostu nie ma umysłu. Ciało i otoczenie stanowią jego tworzywo nie mniej niż szare komórki, gdyż są podłożem procesów poznawczych, których umysł jest podmiotem. W szczególności konstytutywne dla świadomości i samoświadomości są emocje wywołane przez zewnętrzne bodźce i odbierane pierwotnie jako doznania w ciele, a później dopiero jako uświadomione uczucia (Prinz 2009). Z tej perspektywy ciało-umysł (czyli umysł już ucieleśniony, ale jeszcze nieusytuowany w otoczeniu) również stanowi pewnego rodzaju abstrakcję, mianowicie abstrakcję z niepodzielnego, jednolitego, bezpośredniego doświadczenia, które jest dostępne, zanim wkroczy w nie myśl wyróżniająca rozmaite jego komponenty, a zwłaszcza dokonująca podziału na to, co dzieje się wewnątrz organizmu i na zewnątrz niego.

Jeszcze dalej idzie enaktywizm ${ }^{6}$, który w rozszerzony sposób pojmuje nie tylko procesy poznawczo-doświadczalne czy umysł rozumiany jako podłoże takich procesów, ale i samą świadomość. To świadomość ma wykroczyć poza granice naszego ciała. Inspirowany jest enaktywizm fenomenologią i poparty świadectwami neuronaukowymi (Thompson, Varela 2001). Uzupełnia koncepcję ucieleśnionego, usytuowanego poznania myśla że otoczenie nie tylko jest niezbędnym podłożem zachodzenia procesów sensomotorycznych, lecz także jest zwrotnie kształtowane przez organizm i tylko w warunkach wielostronnych oddziaływań mogą zachodzić konstytutywne dla świadomości procesy. Przebiegają one w złożonych, wielopoziomowych interakcjach miedzy trzema dynamicznymi systemami: neuronowym, somatycznym i środowiskowym. Nie są ograniczonymi tylko do mózgu zdarzeniami, zachodzącymi między neuronami. Obejmują samoregulację organizmu, jego związki z otoczeniem fizycznym, biologicznym i społecznym. Zarazem przekraczają podziały na otoczenie, ciało i mózg, które z punktu widzenia funkcjonowania świadomości wydają się co najmniej nieostre, jeśli nie iluzoryczne, a już na pewno nie są natury metafizycznej. Enaktywiści nie sądza, żeby - wbrew filozoficznej fantazji o „mózgu w naczyniu” - można było (choćby tylko w eksperymencie myślowym) oddzielić ciało i otoczenie od istotnych dla świadomości procesów mózgowych, jako coś w stosunku do nich zewnętrznego ${ }^{7}$.

${ }^{6}$ Ang. enactivism. Koncepcja ta nie doczekała się na razie bardziej swojsko brzmiącej polskiej nazwy i być może nigdy się jej nie doczeka.

7 Podobnie twierdzi Hideya Sakaguchi, który ostatnio stworzył laboratoryjnie organoidy mózgowe przypominające działaniem ludzki mózg: jest on zdania, że organoidy te ze względu na brak zaplecza psychomotorycznego nie wytworzą ani myślenia, ani świadomości; problemy bioetyczne mogłyby powstać, dopiero gdyby organoidy miały zapewnione takie zaplecze, por. (Researchers Grow Active Mini-Brain-Networks [2019]). 
Świadomość jest tu pojęta emergentnie, a nie redukcjonistycznie. Nie tylko kształtuje się wskutek powiązań zdarzeń neuronalno-cielesno-środowiskowych, ale i zwrotnie na zdarzenia te oddziałuje. W tradycyjnym podejściu przyjmowano jednokierunkową przyczynową relację, biegnącą od zdarzeń neuronalnych (na które z kolei wpływać może stan ciała czy otoczenia) do treści świadomości. Enaktywizm natomiast dostrzega dwukierunkowy, wzajemny wpływ między stanami świadomości a aktywnością neuronów (w szczególności świadomość ma "odgórnie” integrować rozproszone $\mathrm{w}$ mózgu, zaangażowane $\mathrm{w}$ to samo zadanie poznawcze neurony poprzez synchronizację ich drgań).

Enaktywizm uchyla zatem pogląd, że w procesie poznawczym wchodzą ze sobą w relację dwa istniejące już wcześniej, niezależne od siebie człony: środowisko i umysł, który przyjmuje informacje z otoczenia i tworzy jego reprezentacje. Tym sposobem unika reprezentacjonizmu. Czynniki środowiskowe pojmuje szeroko, z uwzględnieniem społecznych, obejmujących wzajemne oddziaływania między ludźmi. Tym sposobem unika solipsyzmu (Maturana, Varela 1992; Varela, Thompson, Rosch 1991).

Jego mocna wersja - radykalny enaktywizm - idzie jeszcze dalej w kwestionowaniu granic umysłu czy ukazywaniu ich nieostrości. Wysuwa kontrowersyjną tezę, że na podstawowym poziome aktywności mentalnej nie można przeprowadzić podziału na treści poznawcze i nośnik tych treści, czyli sam umysł. A to dlatego, że ów bazowy umysł ma być wolny od zawartości tworzącej jakąkolwiek treść. Mogą tam istnieć intencjonalność, wrażenia zmysłowe i swego rodzaju poznanie, ale bez treści. (Jak widać, elementy te, w tym wrażenia, nie tworzą jeszcze, zdaniem radykalnych enaktywistów, treści). Podstawowe poznanie, uboższe niż podstawowa mentalność, ma się wyrażać raczej behawioralnym odzewem na sytuacje niż reprezentacjami warunków, w jakich znajduje się świat. Umysł bazowy aktywizować się może wyłącznie w relacjach z otoczeniem. Treść pojawia się później, poza podstawowym poziomem, gdy umysł jest już wyposażony w pewne „oprogramowanie”, takie jak np. język, i można go nazwać „umysłem kulturowym”. Treść zwykle towarzyszy językowi, natomiast niewerbalne doświadczenie wizualne bywa od niej wolne (Hutto, Myin 2013). Kontrintuicyjność tego poglądu może brać się stąd, że doznając bodźców wzrokowych lub wyobrażając je sobie w eksperymencie myślowym, nie jesteśmy w stanie uchylić przejściowo swoich kompetencji językowo-kulturowych i bezwiednie do nich sięgamy. Aby wrażenie przerodziło się $\mathrm{w}$ treść, musi być osadzone $\mathrm{w}$ jakimś systemie odniesienia - i z reguły jest, bo trudno abstrahować od wszelkich odniesień.

W enaktywizmie, czy to umiarkowanym, czy radykalnym, następuje dereifikacja świadomości. Przedstawiana jest nie tyle jako intrygujący, 
nie całkiem zbadany obiekt, ile raczej jako funkcja wzajemnych złożonych oddziaływań między bardzo skomplikowanymi strukturami biologicznymi i fizycznymi. Jest dynamicznym procesem, bo i takie właśnie są te oddziaływania. Trudno przy tym wyznaczyć granice procesów konstytutywnych dla świadomości ze względu na nieznające granic wzajemne powiązania zjawisk w świecie.

Przedstawione koncepcje mogą $\mathrm{w}$ warstwie słownej przywoływać skojarzenie z uczuciem oceanicznym. Wszak w obu wypadkach chodzi o poszerzenie granic jaźni czy też granic umysłu, a nawet świadomości. Czy są to jednak tylko akcydentalne, powierzchowne skojarzenia, czy też sięgają głębiej? Jakie relacje zachodzą między filozofią poszerzonego umysłu (nazwijmy tak łącznie wszystkie przedstawione wyżej koncepcje) a filozofią uczucia oceanicznego (nazwijmy tak nie tylko samo to uczucie, ale i refleksję nad nim)?

Z pewnością mają one różne źródła. Filozofia poszerzenia umysłu bierze się z pytań wyrastających z refleksji nad procesami poznawczymi, widzianymi niejako z zewnątrz, z punktu widzenia trzeciej osoby. Nie odwołuje się do żadnego poczucia, odwołuje się natomiast do argumentów, z włączeniem świadectw neuronaukowych. Stara się obiektywnie uzasadniać swoje konkluzje. Natomiast filozofia uczucia oceanicznego bierze się z bardzo osobiście przeżywanego sposobu istnienia siebie i świata. Przeżycie to owocuje pewną wizja, w której ogromny świat, nieograniczony w przestrzeni i w czasie, jawi się jako bardzo bliski i bardzo "nasz”. Bledną z tej perspektywy nasze małe sprawy, którymi zwykle jesteśmy mocno zaabsorbowani. Wizja ta motywuje czasem do prób wyrażenia jej w słowach. Stąd możliwość odnoszenia się do niej, pytania o jej podstawy, zestawiania jej z koncepcjami zobiektywizowanymi i jej oceny na tym tle.

Czy mamy tu do czynienia z całkowicie różnymi sposobami odnoszenia się do świata i znajdowania $\mathrm{w}$ nim swego miejsca, czy raczej są to spojrzenia $\mathrm{z}$ różnych punktów $\mathrm{w}$ tę samą stronę? Bo chociaż podejścia są z pewnością różne, zarówno od strony metodologii, jak i od strony potrzeb, którym wychodzą naprzeciw, przyjmują nieco podobny słowny wyraz i krążą w podobnym obszarze: dotyczą związków świadomości z jej otoczeniem. Przyjrzyjmy się pod tym kątem najpierw teorii umysłu rozszerzonego, a potem koncepcjom umysłu ucieleśnionego, usytuowanego i enaktywnego.

Inspirowana rozwojem techniki teoria umysłu rozszerzonego, czyli pierwsza z przedstawionych koncepcji, mimo swej nazwy wydaje się nie mieć wiele wspólnego z filozofią uczucia oceanicznego. Wprowadza ona po prostu do epistemologii nowe wątki pod wpływem zmian technicznych zachodzących we współczesnym świecie w realizacji procesów poznawczych. Należy przede wszystkim do epistemologii, a do filozofii umysłu 
- niejako wtórnie, o tyle, o ile wspomniane zmiany w przebiegu procesów poznawczych motywują do rewizji koncepcji podmiotowości. W jednym może punkcie zbieżna jest z filozofią uczucia oceanicznego, ale tylko w swej późniejszej, zmodyfikowanej wersji: oto pojmuje umysł nie jako obiekt, lecz jako proces. A uczucie oceaniczne raczej nie pozostawia miejsca na dystans wobec własnego umysłu niezbędny do tego, aby przedstawiać go sobie niejako z zewnątrz, jako jeszcze jeden obiekt pośród wielu innych obiektów, zatrzymany przez schematyzującą myśl w formie statycznej. Uczucie oceaniczne to raczej doświadczanie własnej jaźni z chwili na chwilę w nierozerwalnym związku z wszelkim istnieniem. Jego przedmiotem jest jaźń doświadczana, a nie wyabstrahowana z doświadczenia. A doświadczanie, podobnie jak i uczucie, jest procesem, nie obiektem.

Nieco inaczej może wyglądać zestawienie filozofii uczucia oceanicznego z ciągiem koncepcji dotyczących umysłu ucieleśnionego, usytuowanego i enaktywnego. Wychodzą one od pytań o istotę i źródła zadziwiającego fenomenu, jakim jest umysł/świadomość. Pytania te wydają się bliskie zagadnieniom egzystencjalnym, poruszającym nie tylko profesjonalnych filozofów, i zdają się bliższe pytaniom o granice czy naturę jaźni niż pytaniom o granice procesu poznawczego w świecie techniki. Teoria umysłu rozszerzonego dotyczy raczej procesu poznania niż świadomości. Ma wy234 miar raczej konkretny i pragmatyczny niż egzystencjalny.

Natomiast enaktywizm i poprzedzające go koncepcje, choć powstały w sposób zobiektywizowany, dotykają kwestii, które przez wielu ludzi mogą być przeżywane bardzo osobiście i mogą mieć znaczenie dla ich sposobu znajdowania się w świecie. Badaczowi zainteresowanemu tą problematyką znacznie bliższe może być sięgnięcie do introspekcji niż zwolennikowi teorii umysłu rozszerzonego. Nawet jeśli kieruje się przede wszystkim wiedzą neuronaukowa, może obok tego potwierdzać w jakimś stopniu w swoim własnym prostym, bezpośrednim doświadczeniu wizję umysłu, dla którego konstytutywne są oddziaływania neuronalno-somatyczno-środowiskowe. Takie dodatkowe „potwierdzenie” nie ma pewnie większego znaczenia w świecie nauki, lecz może je mieć w naszym życiu i w doznawaniu związków ze światem, podobnie jak uczucie oceaniczne. Znamienny jest tu przykład F. Vareli, jednego z twórców enaktywizmu, który był także jednym z inicjatorów sympozjów na temat związków współczesnej nauki $\mathrm{z}$ medytacją. Reprezentuje on dwa podejścia do tej samej kwestii - istoty świadomości - i próbuje je do siebie zbliżyć do siebie wzajemnie. Podkreśla praktyczny, życiowy wymiar enaktywnej koncepcji świadomości i wskazuje sposoby na jej zinterioryzowanie, a nie tylko przyjmowanie jej do wiadomości na podstawie świadectw czy rozważania argumentów.

Jednym z takich sposobów jest medytacja, i na nią też wskazuje Varela. Może się ona zdawać jakoś bliska uczuciu oceanicznemu, i to nie tylko 
ekspertom od tego uczucia, ale także komuś jedynie powierzchownie wprowadzonemu w temat. Wszak uczucie oceaniczne wydaje się na tyle odległe od potocznych doświadczeń, że wymagać może zdystansowania się od codziennych, absorbujących spraw i wyciszenia umysłu, aby znalazło się w nim miejsce na coś, co wcześniej nie dochodziło do głosu. A wyciszenie i dystans od codziennych mentalnych uwikłań oferuje właśnie medytacja.

Jej powiązania z uczuciem oceanicznym nie są jednak konieczne, bo jedno i drugie może funkcjonować niezależnie. Uczucie oceaniczne nawiedza pewne osoby spontanicznie, bez żadnych w tym celu podejmowanych zabiegów. Pojawia się czasem niespodzianie, czasem wywołując zaskoczenie. A medytacja może nie być, i w wielu wypadkach nie jest, inspirowana dążeniem do uczucia oceanicznego. Może zmierzać np. do odprężenia ciała, uśmierzenia niepokoju, złagodzenia bólu, zrównoważenia emocji (i tak też czyni wspomniana wyżej praktyka uważności, stosowana w różnego rodzaju terapiach). Czasem medytacja nie stroni od myśli i ma charakter werbalny - np. gdy poświęcona jest refleksji filozoficznej czy religijnej, ale nie takiej, która polega na ważeniu argumentów i formułowaniu sądów, i nie tyle szuka odpowiedzi na pewne pytania, ile raczej odsłania znaczenie pewnych kwestii dla ludzkiej egzystencji, a wskutek tego może wpływać na ludzkie potrzeby i dążenia i na sposób doświadczania rzeczywistości.

Medytacja nie musi zatem prowadzić bezpośrednio do uczucia oceanicznego. Może jednak prowadzić do niego pośrednio, przygotowując pod nie grunt. Prosta, wyciszająca medytacja pozwala odłożyć na bok różne mentalne nawyki, na co dzień tak mocno w nas zakorzenione, że nawet niezbyt jesteśmy ich świadomi. Czyni tym sposobem miejsce na ewentualne nowe spojrzenie na świat i na doświadczenie nieznanych nam wcześniej sposobów znajdowania się w nim - np. na uczucie oceaniczne. A głębsza medytacja kieruje umysł ku sprawom trudno uchwytnym, lecz istotnym w ludzkim wymiarze. Może skutkować odczuciem tego, co Marian Przełęcki nazywał metafizyczną wizją świata, wskazującą na jego ukryty sens (Przełęcki 2007). Zapewne wpisuje się w nią także uczucie oceaniczne.

Bywa jednak i tak, że uczucie to jest bezpośrednim celem medytacji, choć w kontekście różnych metod medytacyjnych nie mówi się „uczuciu oceanicznym" (określenie to, choć wyraża treści uniwersalne, sprzęgło się już trwale z nazwiskiem Freuda i Rollanda), lecz używa się innych słów, jak np. poczucie jedności ze wszechświatem czy doświadczenie obecności Boga. Pewne sposoby medytacji przewidują przy tym stopniowe, przebiegające etapami poszerzanie granic umysłu. I tu okazuje się rzecz bardzo ciekawa: etapy te odpowiadają z grubsza kolejnym koncepcjom dotyczącym umysłu ucieleśnionego, usytuowanego i enaktywnego. W medytacji 
tego rodzaju najpierw następuje zjednoczenie umysłu z ciałem, jego receptorami i doznaniami - doświadczanie odbierane jest jako jakościowy monolit, a nie jako relacja niezależnych członów. Dopiero wkraczająca $\mathrm{w}$ takie doświadczanie myśl abstrahuje $\mathrm{z}$ niego w celach praktycznych odrębne człony: ciało i umysł. Jednakże w obszarze doświadczania w znacznej mierze uwolnionego od wpływu myśli stanowią one jedność. Gdyby już po powrocie do świata abstrakcji i myślowych przyzwyczajeń chcieć post factum to jakoś wyrazić, być może koncepcja umysłu ucieleśnionego okazałaby się użyteczna.

Na kolejnym etapie procesu medytacyjnego pogłębia się odchodzenie od mentalnych nawyków i rozpoczyna się jednoczenie ciało-umysłu $z$ otoczeniem. Jest to naturalna konsekwencja pierwszego etapu: wszak do otoczenia nie inny mamy bezpośredni dostęp niż przez nasze ucieleśnione receptory. Dobrze zazwyczaj ugruntowana granica między naszym wnętrzem a zewnętrzem zdaje się tracić na znaczeniu. Te dwa obszary również mogą być uznane za użyteczne abstrakcje z procesu doświadczania, coraz bardziej uwalnianego od wpływu myśli. Etapowi temu odpowiada koncepcja umysłu usytuowanego, która ze swej strony także wydaje się naturalną konsekwencją koncepcji poprzedniej (umysłu ucieleśnionego). Następnie w medytacji owa jedność z otoczeniem wzmacnia się i poszerza - a racje na rzecz przyjęcia takiego podejścia z perspektywy trzecioosobowej przedstawia enaktywizm.

Wspomniane abstrakcje z jednolitego procesu doświadczania, do których tak dobrze przywykliśmy i które przeważnie niepodzielnie rządzą $\mathrm{w}$ naszych myślach, są niezmierne przydatne $\mathrm{w}$ sprawach praktycznych i w ułatwianiu codziennej egzystencji (podobnie jak i szereg innych abstrakcji). Natomiast medytacja skłaniająca do bezpośredniego i osobistego powrotu do źródeł umysłu ma również na celu względy praktyczne, lecz innego rodzaju, mianowicie uśmierzenie doznawanego przez niektórych ludzi dyskomfortu związanego z poczuciem separacji od otoczenia oraz uwolnienie od nawyku postrzegania siebie jako wyróżnionego obiektu we wszechświecie, który zasługuje na szczególną uwagę, a pewnie i na szczególne względy, i stanowi główny punkt odniesienia wobec różnych okoliczności życiowych. Nic dziwnego, że wiele tradycji religijnych chętnie sięga do medytacji, upatrując $w$ niej środka pozwalającego uśmierzyć czy ograniczyć egotyczne nastawienie do świata, a wyrobić większą bezstronność i troskę o innych. Czyni to, zachęcając do zjednoczenia z tym, co jawi się jako wielka wartość - na gruncie religii jest to zwykle Bóg, ale w szerszym kontekście także Natura, metaforyczny ocean czy może coś jeszcze innego.

Zadziwiające jest natomiast, że tak wyraźne analogie są widoczne w dwóch tak różnych stylach myślowych (by użyć określenia Ludwika 
Flecka): w odwiecznym podejściu zmierzającym do wszechobejmującego przekroczenia granic własnej jaźni, kuszącego obietnicą jakiegoś bliżej nieokreślonego spełnienia, oraz $\mathrm{w}$ znacznie nowszych próbach zobiektywizowanego, bliskiego tradycji scjentystycznej spojrzenia na umysł w sposób, jakiego dawniej filozofia zachodnia nie znała.

\section{Bibliografia}

Adams F., Aizawa K. (2009), Defending the Bounds of Cognition, [w:] The Extended Mind, R. Menary (red.), MIT Press, Cambridge, s. 67-80.

Clark A., Chalmers D. (1998), The Extended Mind, „Analysis” 58, s. 7-19.

Freud S. (1998), Kultura jako źródło cierpień, tłum. R. Reszke, [w:] idem, Pisma społeczne, Dzieta, t. 4, Wydawnictwo KR, Warszawa, s. 163-227.

Hutto D.D., Myin E. (2013), Radicalizing Enactivism: Basic Minds without Content, MIT Press, Cambridge-London.

Jedynak A. (2014), Contemporary Western Concepts - a Step toward Eastern Mentality, "GSTF Journal of General Philosophy" 1, 1, s. 58-63.

Kabat-Zinn J. (2014), Gdziekolwiek jesteś, bądź, Czarna Owca, Warszawa.

Lakoff G., Johnson M. (1999), Philosophy in the Flesh: The Embodied Mind and its Challenge to Western Thought, Basic Books, New York.

Logan R.K. (2007), The Extended Mind: The Emergence of Language, the Human Mind and Culture, University of Toronto Press, Toronto-Buffalo-London.

Loughlin V. (2019), Extended Mind, Extended Conscious Mind, Enactivism, http://victorloughlin.com/downloads/PhDThesis.pdf (dostęp: 24.05.2019).

Maharaj A. (2017), The Challenge of the Oceanic feeling: Romain Rolland's Mystical Critique of Psychoanalysis and His Call of the "New Science of the Mind", "History of European Ideas", https://philarchive.org/archive/MAHTCO-17 (dostęp: 19.03.2019).

Maturana H.R., Varela F.J. (1992), The Tree of Knowledge: The Biological Roots of Human Understanding, Shambhala, Boston.

Menary R. (2009), Cognitive Integration and the Extended Mind, [w:] R. Menary (red.), The Extended Mind, MIT Press, Cambridge, s. 227-243.

Pecher D., Zwaan R.A. (red.) (2005), Grounding Cognition: The Role of Perception and Action in Memory, Language, and Thinking, Cambridge University Press, Cambridge.

Prinz J.J. (2009), Are Emotions Feelings?, „Journal of Consciousness Studies” 16, 9, s. 9-25.

Przełęcki M. (2007), Horyzonty metafizyki, Wydawnictwo Naukowe Semper, Warszawa.

Researchers Grow Active Mini-Brain-Networks (2019), "Science Daily”, 27.06.2019, https:// www.sciencedaily.com/releases/2019/06/190627113945.htm (dostęp: 18.08.2019).

Robbins P., Aydede M. (red.) (2009), Cambridge Handbook of Situated Cognition, Cambridge University Press, Cambridge.

Rosch E., Varela F.J., Thompson E. (1991), The Embodied Mind: Cognitive Science and Human Experience, MIT Press, Cambridge.

Thompson E., Varela F.J. (2001), Radical Embodiment: Neural Dynamics and Consciousness, „Trends in Cognitive Sciences" 5, s. 418-425.

Wilber K. (2002), Psychologia integralna. Świadomość, duch, psychologia, terapia, Wydawnictwo Czarna Owca, Warszawa.

Williams M., Teasdale J., Segal Z., Kabat-Zinn J. (2013), Świadoma droga przez depresję, Wydawnictwo Czarna Owca, Warszawa. 
Streszczenie: Granice jaźni, granice umystu

$\mathrm{Na}$ dwa sposoby przejawia się w filozofii pojmowanie jaźni czy umysłu jako wykraczających poza zwyczajowo przyjmowane granice. Po pierwsze - jako uczucie jedności z wszelkim istnieniem, wszechświatem, przyrodą czy Bogiem, znane ludziom różnych czasów i kultur. Romain Rolland nazwał je "oceanicznym” i upatrywał w nim podstaw duchowości. Po drugie - jako szereg powstałych ostatnio koncepcji, które pojmują umysł bardzo obszernie, włączając doń elementy otoczenia (teoria umysłu rozszerzonego, koncepcja umysłu ucieleśnionego i usytuowanego, enaktywizm). Różnią się te dwa nurty podejściem, genezą i metodą. Uczucie oceaniczne jest bardzo osobiste, raczej odczute niż przemyślane, wpływające na sposób przeżywania własnego istnienia. Natomiast wspomniane koncepcje są zobiektywizowane, badają umysł z zewnątrz, uwzględniają racjonalne argumenty i świadectwa neuronaukowe. Mimo tych różnic te dwa nurty koncentrują się wokół podobnych spraw. Co ciekawe, stopniowa radykalizacja różnych koncepcji poszerzonego umysłu wydaje się przechodzić przez podobne stadia co stopniowe poszerzanie poczucia jaźni w pewnych typach praktyki medytacyjnej.

Słowa kluczowe: enaktywizm, jaźń, medytacja, uczucie oceaniczne, umysł rozszerzony, umysł ucieleśniony, umysł usytuowany

Summary: The Limits of the Self, the Limits of the Mind

Philosophy sees two trends which position the self, or the mind, as exceeding beyond the typically accepted boundaries. Firstly - as the feeling of oneness with all being, the universe, nature or God, known through different cultures and ages. Romain Rolland called this the "oceanic feeling" and considered it the basis of spirituality. Secondly - as a series of more recent concepts, with a very broad understanding of the mind inclusive of some elements of the surroundings (Extended Mind Theory, the concept of embodied embedded mind, enactivism). Those two trends differ in their approach, origin and method. The oceaning feeling is very personal, felt rather than conceived, affecting the experience of one's existence. Whereas the aforementioned concepts are objectified, they examine the mind externally, considering rational arguments and neuroscientific testimony. Despite these differences though, both trends focus on similar issues. What is interesting, the gradual radicalisation of the different concepts of an extended mind seems to follow similar stages as the gradual broadening of the sense of self in some types of meditative practice.

Keywords: enactivism, embodied embedded mind, extended mind, self, meditation, oceanic feeling 